\section{Epizootic of Herpes-like Virus Infection in Goldfish, Carassius auratus in Taiwan}

\section{Pen Heng Chang ${ }^{1 \times}$, Shu Hwae Lee ${ }^{2}$, Hsien Choung Chiang ${ }^{3}$ and Mıng Hwa Jong ${ }^{2}$}

${ }^{\dagger}$ Department of Veterinary Medicine, College of Agrıculture, Natıonal Talwan University, Taipel, Taiwan, ROC

${ }^{2}$ Talwan Provincial Research Institute for Animal Health, Tansu, Tarwan, ROC

${ }^{3}$-Lan Livestock Disease Control Center, I-Lan, Tawan, ROC

(Recelved January 11, 1999)

Key words: goldfısh, herpes-lıke vırus, histopathology, Talwan, Carassins auratus

In May of 1995, an epızootıc occurred in goldfish fry at a breedıng colony in northeast Taiwan resultıng in 90 percent loss of fry In the study, we did histopathological and ultrastructural studies in diseased fish and report the association of a herpes-lıke virus with this epızootıc

\section{Materials and methods}

Goldfish (20 to 25 days old, $15-20 \mathrm{~cm}$ body length) from a population with an increased mortality in the breeding colony were subjected to necropsy and for pathogen isolation Samples were taken from liver, spleen, and kıdney of morıbund fish and inoculated onto brain heart infusion agar (BHI) (Difco $\left.{ }^{T M}\right)$, which were Incubated at $25^{\circ} \mathrm{C}$ for $48 \mathrm{~h}$ Moribund fish collected from the breeding colony were fixed in $10 \%$ neutral formalın, embedded ın paraffın, sectıoned at $5 \mu \mathrm{m}$, and staıned with Mayer's hematoxylın and eosın Samples of lıver, spleen, heart, head kıdney and trunk kıdney of 20 moribund fish were pooled, homogenized in phosphate buffered salıne (PBS) to give a $10 \%(\mathrm{w} / \mathrm{v})$ suspension and centrifuged at $3000 \mathrm{Xg}$ for $20 \mathrm{~min}$ at $4^{\circ} \mathrm{C}$ The supernatant was centrifuged at $100,000 \mathrm{Xg}$ for $10 \mathrm{~min}$, the pellef was negatively stained with $2 \%$ phosphotungstıc acıd and examined usıng an electron microscope

\section{Results}

In December 1994, 200 brood goldfish were introduced into a goldfish hatchery in northeast Taiwan The introduced fish died spontaneously without a cause

\footnotetext{
"Corresponding author

E-mall penheng@cc ntu edu tw
}

being determined, and 120 fish were left by March 1995 , the mortality of introduced fish was 40 percent. Selected new brood fish were mixed with established brood fish in the pond for cross breeding at about $22^{\circ} \mathrm{C}$ water temperature Eggs were hatched, and fry were transferred to rearing units at 70,000 fry/unit At twenty days old, fish in one unit began to show anorexia, lethargy, and yellowish discoloration Fish in the other 2 units showed similar signs a few days later Most fish began to die at the 4th $d$ in the units and resulted in a mortality of $90 \%$ of approximately $2,000,000$ fry in four units

There was yellowish discoloration of skın associated with natural infections of goldfish No pathogenıc bacteria were isolated from moribund fish The lesions were found in visceral organs and skın of natural infections of fish The interstitial tissue of trunk kidney revealed multiple focal necrosis with mild infiltration of macrophages The affected cells in the necrotic area had enlarged nucleı showıng promınent chromatın margination (Fig 1) Simılar lesıons were found in the myo-

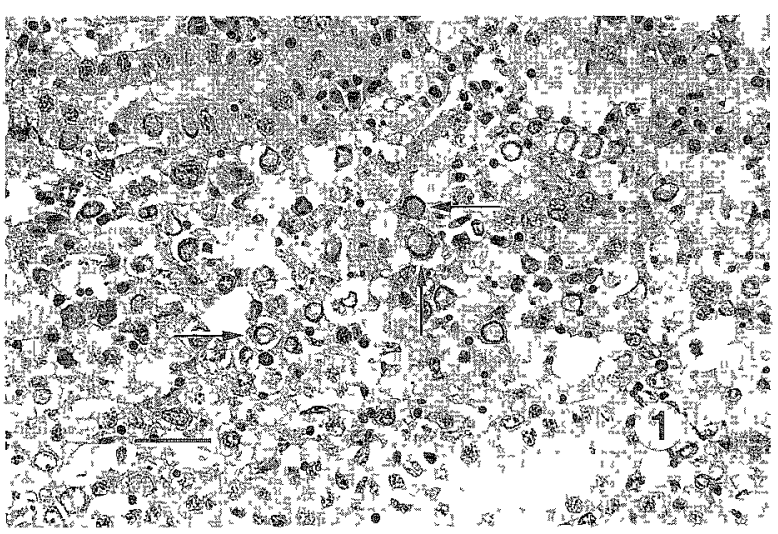

Fig. 1. Natural herpes-lıke virus infections of goldfish, Carassius auratus The affected trunk kıdney showed enlarged nucles (arrow) in the necrotic cells $\mathrm{H} \& \mathrm{E}$ bar $=200 \mu \mathrm{m}$

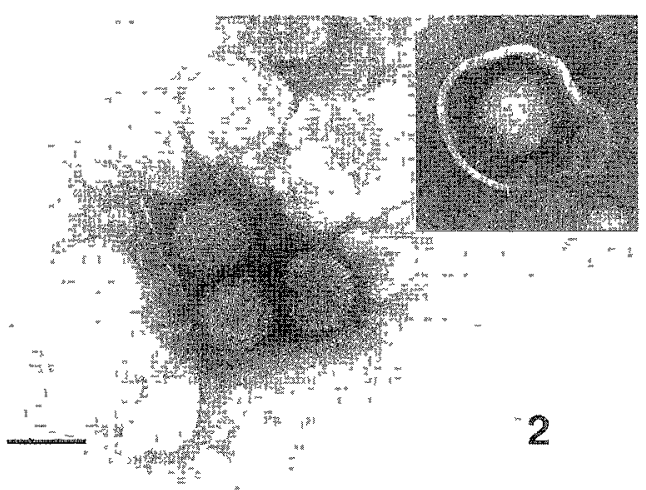

Fig. 2. Natural herpes-lıke nucleocapsids (center) and enveloped virion (upper right) in preparation from pooled visceral organs of naturally infected goldfish negatively stained with $2 \%$ phosphotungstic acid bar $=100 \mu \mathrm{m}$ 
cardia of heart, lamina propria of small intestine, exocrine tissue of pancreas, head kidney, and epidermis and dermis of skin. There was also cloudy degeneration in some renal tubule epithelia of trunk kidney.

TEM examination on thin sectioned and negatively stained samples showed both nucleocapsid and enveloped virion. The viral particles were hexagonal with intranuclear nucleocapsids of 100 to $110 \mathrm{~nm}$ in diameter and intracytoplasmic enveloped virions of 175 to $225 \mathrm{~nm}$ (Fig. 2). The morphology and size of the viral particles fell within Herpesviridae ${ }^{7,9}$.

\section{Discussion}

Herpesviruses associated with proliferative conditions of the epidermis ${ }^{1,2,4,5,6,8,10)}$ or systemic diseases in fish have been reported ${ }^{3,11}$. The epidemiology of the case shared some similarity to herpesviral haematopoietic necrosis (HVHN) infection of goldfish in Japan ${ }^{3)}$. Both caused high mortality at about $22^{\circ} \mathrm{C}$ water temperature. The morphology and the size of the causative virus and host cell range were similar too. In the epizootic, the lesions were characterized by focal necrosis in visceral organs, and epidermis and subcutaneous tissue of skin; the affected cells in the necrotic area had an enlarged nuclei showing prominent chromatin margination. Jung and Miyazaki ${ }^{3)}$ had reported HVHN virus infected goldfish induced similar focal necrosis in various visceral organs except for the appearance of enlarged nuclei in affected cells.

In this epizootic, the hatchery owner had introduced brood goldfish before spawning. Prior to this introduction there was no known herpesviral infection of goldfish in Taiwan. It is speculated that the virus was introduced with the imported goldfish.

\section{References}

1) Bradley, T. M., D. J. Medina, P. W. Chang, and J. Mcclain (1989): Dis. Aquat. Org. 7, 195-202. 2) Hedrick, R. P., J. M. Groff, M. S. Okihiro, and T. S. McDowell (1990): J. Wildl. Dis. 26, 578-581. 3) Jung, S. J., and T. Miyazaki (1995): J. Fish Dis. 18, 211-220. 4) McAllister, P. E. (1993): Fish medicine (ed. by M. K. Stoskopf). W. B. Saunders Company, Philadelphia, pp. 284-299; 380-407; 697-710. 5) McAllister, P. E., and R. L. Herman (1989): Dis. Aquat. Org. 6, 113-120. 6) McAllister, P. E., B. C. Lidgerding, R. L. Herman, L. G. Hoyer and J. Hankins (1985): J. Wildl. Dis. 21,199-204. 7) Post, G. (1987): The textbook of fish health (ed. by P. George) TFH Publications, Inc. NJ, pp. 93-147. 8) Shih, H. H., C. C. Lu, and S. N. Chen (1993): COA Fisheries Series, Fish Disease Research (XIII). 86-96. 9) Smail, D. M., and A. L. S. Munro. (1989). Fish pathology, 2nd ed. (ed. By R. J. Roberts). Bailliere Tindall, London. pp. 173-186. 10) Steinhagen, D., P. Kruse, M. Neukirch. (1992): Dis. Aquat. Org. 13, 225-229. 11) Thune, R. L. (1993): Fish medicine (ed. By M. K. Stoskopf). W. B. Saunders Company. Philadelphia. pp. 521-523. 